\title{
TWO CASES OF SYRINGOMYELIA COMPRATIVE STUDY WITH REFERENCE TO 49 CASES REPORTED IN JAPAN
}

\author{
by \\ Saburo Sato and Akira Mayama \\ Research Institute for Tuberculosis and Leprosy, Tohoku University, \\ Sendai. \\ (Abstract)
}

\begin{abstract}
Syringomyelia is a comparatively rare disease and is difficult to distinguish from certain cace of neural Leprosy. The authors recognized two caces, one is a 48 years old farmar's wife who was complaining of sensory, motory and trophic disturbances of the upper extremities with ape-hands, since a ha'f year; the other is a 39 years old woman who was suffering from sensory, motory and trophic disturbances of four extremities with ape-hands, talipes equinovarus and kyphosis. She showed pupillary stymptoms such as anisocoria and stiff pupil accompanying Horner's syndrome, since about 20 years. In the latter case, the left auricular nerve and the skin of the right forearm were examined biopsically, but none of them showed any bacteriological or histological changes.

The said cases were scrutinized, comparing with 49 cases, reported hither to in Japan, especially in regard to sex, age, favourite localization, cardinal symtomes, such as sensory, motory and trophic disturbances, deformity of the extremities or vertebral column and pupillary symtomes etc.
\end{abstract}

\section{脊檤空洞症に就て その 2 例と本邦報告例との比較觀察

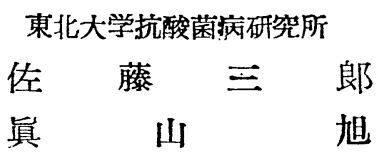

頛の猃断は一般にはさして团奞ではないが，時により 甚げ難しいことがある。その代表的な場合に一群の脊祭

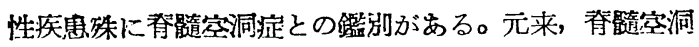
症は比較的稀な疾思とされ，本邦での郝告例も50数例飞 渦ざない。われわれは渦去I0年に 2 例を觀察したので， 荻にその詳細を述へ，併せて記載のやら゙明らかな本邦報 告の49例と対比しつつ, 主として賴との鑑淤点に留意し 比較検领したいと思ふ。

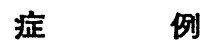

第 1 例

初䛦。1 1942.6 .27 . 4 年。女。農。

家庭歴 父系の祖父母の死因不詳。母系の祖父母は共

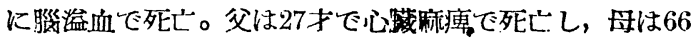
才で㯬在，同胞 5 人も皆健在である。既往症 生来健康 飲酒, 契煙せず。性病は否定。初潮17才。現症 47 才の 
12月始めより，兩上肢に知覚鈍麻部があるのに気付いた が，夯第に手指にる抢よび 2 ヶ月後には手指の運動踣碍 を件つたので、某医の下で腿気として加療したが全く効 がなく悪化するのみであつた。全身所見 体格中等度。

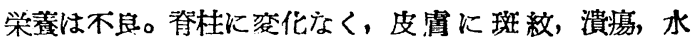

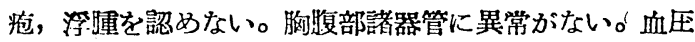
最高110, 最低70。ッ反広陽性。血沈 1 時間犆 7。ワッ セルマン反忘阷性。局所所見 瞳孔は円形で同大である が対光反射やや鈍。耳悬咽喉に異常がない。兩手に著明 な觜爪手があり，指間筋の萎縮は著しく手指の運動㜔碍 を件つている(写傊 1 )。兩上肢に溫度覚, 涌覚の鈍麻が あり，特に左側では脫失の状態であつたが，觸覚の異常 は殆ど認められなかつた。下肢では知覚・栄录・運動䧛

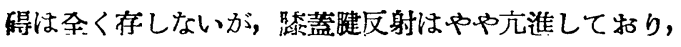
步行はやや失調である。但し病的反射は存しない。尿所

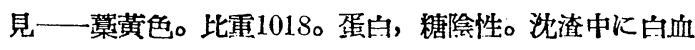
球良䟢的。血液所見一一赤血球 119 万。白血球 8600 。血 色素量ザーリー76。血液渗は嫩エオジン性白血球 $4 \%$, 恕中性（桿状核 $2 \%$ ，分葉核 $66.5 \%$ ），淋巴球 $21 \%$ ，大

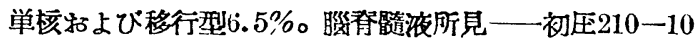
$0 x$ 採取一終圧160(臥位)。無色唀明。グロブリン反応( フンネ・アヘルト第一相、ペンテイ）阥性。細胞数 $3 / 4$ 。

第2 例

初診。1950.9.6。39才。女。無職。

家族歷父系, 母系の祖父母の死因共に不詳。父は60 才で健在であるか，母は37才で死亡したという（死因不 詳)。同胞なく, 未婚。既往症 生来健康で著思を知ら なかつた。飲酒, 契西せず。現应 小学校卒業後, 某紡 謮工場に女工として勤務していたが，19才の夏に全身潦 忘, 削鼠を来し某医にロイマチスと診断された。治療を

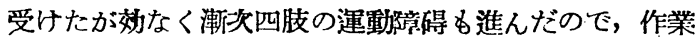
能力低下し退職した。その後も指趾の屈曲, 四肢殊に手 足の削溲站に運動㜔碍は漸進し, 篒柱後彎が第に明ら

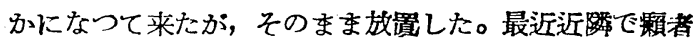
との繁が高くなり，某保健所の紹介で当方に受診した。

全身所見 体格, 栄鸢共に中等。会杜は高度の钼, 胸

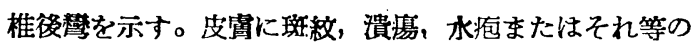
激痕, 浮腫なく，胸椱部內藏に異常を認めない。血圧最 高 120 , 最低 50 。 マン，村田反応共に郚性。

局所所見

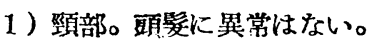

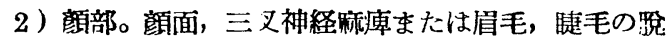
落はない。眼定状としては対光反射やや遐鈍, 䏸孔は類
円形で不同症（右>左）があり，左眼裂が右に比し㚒少 であるが，眼睑下垂，鬼眼，角喷炎，眼球後退，眼球振

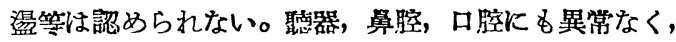
悬汁中の類菌検查も陰性に終つた。大耳仝神経は右がや や觸知されたが，頸部淋巴腺の軍脹はない。

3）上肢。兩手に著明な䉆爪手，手掌站に前膊筋の萎

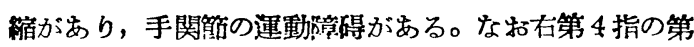
3 指骨がレ楾検查で挩落しているのが瑟必られたが，女

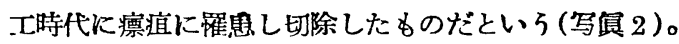
橈骨, 尺骨, 正中神経の肥唇, 时部淋巴腺の睡脹はな い。唯前兩膊の尺側站に尺侧牛皮冒に溫度賞, 哔覚の鈍 麻があつたが、臅党の異常は㱠ど認められなかつた。

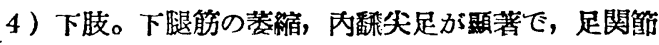
の運動稖䅞もあるが，趾骨の脫落，足染孔症，腓骨神経 の肥厚等はなく(写傊 3 ), 溫度覚, 痛賞は兩太褪前面に おいてやや軽度の鈍麻を証明し得たが，用喾の異常は認 められない。淡蓋腱反射はやや蓬しているが，ババン スキー カオッペンハイム, メンデル等の異常反射は存し ない。但し內䧽尖足のためかロンベルグは多少認められ た。步行せしめると著明な㾤撃性步行をする。

5 ）尿所見。藏黄色。蛋白, 㜍何れも陰性。沈淖中に 痕跡的の血球, 類口柱, 膀胱上皮細胞を認める。

6）血液所見。赤血球 480 万。白血球 2200 。血色素量

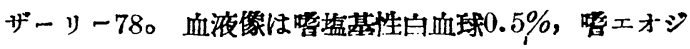
之性 $2 \%$, 照中性（後骨髓細胞 $2 \% ，$ 桿状核 $21 \%$ ，分葉 核 $45 \%$ )，淋巴球 $25.5 \%$ ，大単核むよび移行型 4\%であ つた。

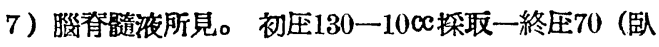
位)。無色透明。PH 7.4。総蛋白量ニシャルすイ。グロリ ン反応 (ノンネ・アベルト第一相, ペンデイ) 阥性。細 胞数 3 \% 巴球癙䠌的。

8 ) 病理組織学的所見。右大耳介神経站に右前膞伸湘 尺側の皮冒の一部をそれそれ切除し，細菌学的站に組織 学的炕調べたが，㱠んど何等の特記すべき所見を認めな からた。

\section{總括及び考案}

1824年 Ollivier d'Angers の命名による本症は比較

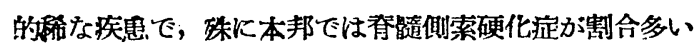
のに拘らず，本症はやや稀れとされて括り，われわれの 調べた籍囲ではわれわれの 2 例を含めて特よそ53例（川 口の 8 例は中に重複した報告例があると思われたので， 一応除外した）を算したが，その中性别の記載の明かな 50例に就て見ると，男 28 例(58)、女 21 例 (42\%) で従来 
男は女の 2〜3 倍を占めると考えられていたが，それほ とでないことか知られる。年令関係は物明した 49 例中 10 １9才，4例，20〜29才，13例，30〜39才，19例，40〜 49 才特よび50～59才は各々 5 例，60才以上 3 例で 20 拉 び30才代に最も多く，その過牛数を占めていた。

本店の特致とするところは, 主として四肢殊に前溥打 よび手の知覚草䄈, 筋萎縮, 栄養・運動䧛碍等で手指の 屈曲, 畸型や萗淔による断節等加出䅐し易く, 彷つて顆 殊に神経顀との鑑別か間題となる。それに関しては， Jadassohn の皮学科学広本に特ける Klingmüller の 所䜠中や，Jeanselme の著書に詳述されて牱り蛇足を 要しないが，要するに本症ではゆわゆる節狱に分布した 多くは1售に位する知覚陵㥂があり，しかも知覚解㒕が

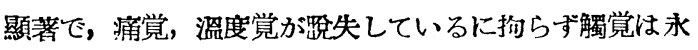
く侵されぬことが多く，一般に神経肥厚を件わず，乙ば しば脊柱の彎曲や瞳孔淀状, 病的反射, 手指震領を見る ことによつて穎と区別出来ると云われる。併しこれ等の

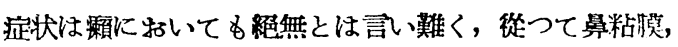
皮虞面等からの瀨菌の証明が殆んど不能である純粹な神 経顆の場合には, 兩者の鑑別な極めて因僅で, 経過に俟 つ以外に手段のない㘯合すらある。 Rietti(Klingmüller

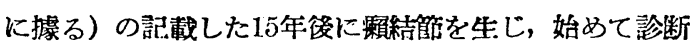
が確定した神経䝷の 1 症例は正にこれに当るすので, 瞳 孔の不同症と対光反射の遅延, Romberg 現乘等があ り, 知覚郣碍も極めて不定型的であつたと云う。Klin-

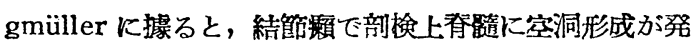
見された場合に，Gerber 等および Piatinitzky 等の 2 例があり，反対に本症の空洞內壁の梁抹棒本中に抗酸性 菌を証明したものに, Petana 等の 1 例があつた。併し 前者の埸合は洗行性，後天性に空洞症を合併した例と考 える方がよく，後者に至つては切片中に何等菌を発見し 得なかつた点より, 偶発的に類似抗酸性菌をみたものに 過ぎまい。即ち今日の一致せる見解では, 純粹な顀性装 化にあつては，脊膸仕空洞を作ることは殆んど考㐫得な いからて (Jeanselme)， それは続発的かつ限局性の状

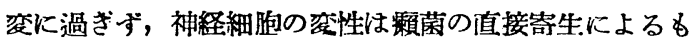
のと，末梢神経病変が上行性に波及したものと 2 軼の岸 因基づくすのであると云う(光田)。一方，梁林樏本中 に抗酸性菌を証明したとしても值ちにこれを以て賴菌と 断ずることは，極めて危険なのは言万迄もないことで， 身体皮表や內藏, 分泌物中にはしばしば類似抗般性菌か あつて過誤の因をなす外, 検查に用いる器具伷来する ことも步り得るからで，われわれるをた第2例の大再介 神経梁抹摽本作製に際し，神経片を擂譈した乳錸を著沸
渭毒するに際し，注意を念つたため同しよらな誤をりを 犯すところであつた。

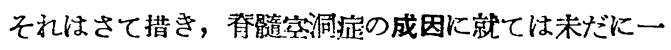
致した見解はないが，要するに発育㜔碍に基づく脊盟生

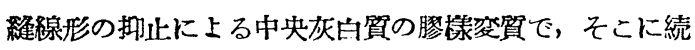

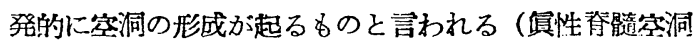

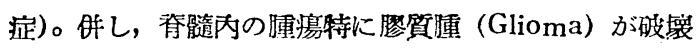
しても(川口, 中村, 作藤, 本間, 田嗗, 山口の例), ま た外傷その他による脊膸內出血（伊藤，西野，白川の

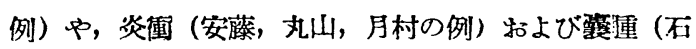
山, 伊藤, 門脇, 三浦, 中田, 吉田, 津田の例) 加基焚 となつて空洞を形成することもあるのは圌知である（鿊

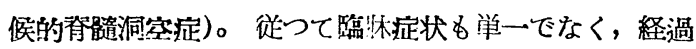
も一般には極めて慢性ではあるが，時には筑激に経過す ることもあると云万(伊藤, 岩男, 佐藤・本間, 田端, 津田, 月村, 山田の例)。前訳51例中, 手䘗をたは剖検に より成因の判明したものは, 睡瘍性のもの 3 例（中村, 山口，田嶼），慢性脊髓焱（丸山）拉よび代膿症(月村）

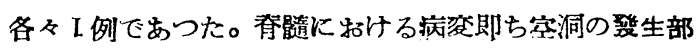

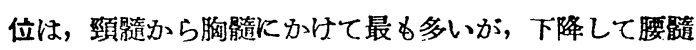
にも拉よぶことがしばしばある（井上・光沢，岩男，門 胁, 西野, 碓居)。また時には上行して延髓, 惱橋にも 牤よぶことすらある（青山，井上・光沢，門㘿，中村， 西野, 新田, 大橋, 白川; 大橋・周々木, 所田, 辻)。

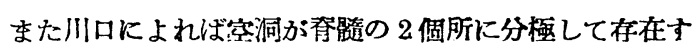
ることもあると云ら。われわれの第 2 例もそれに当るる のと思われた。

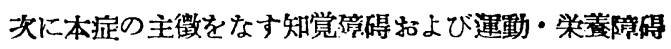
の中, 最も特異なるものに就て, 上記51例と対比しつつ 少しく济へてみよろ。

症狀玩出部位 空洞の好発部位加ら見て子上肢に多い ことは明瞭で，㙞沼㸚授による85\%は上肢であると言わ れるが，本邦の51症例で上肢が21例(41.2\%), 下肢が 5 例 $(9.8 \%)$, 四肢17例 $(33.3 \%)$, 宸扎よび頸 2 例，記 載なきもの 6 例であつた。

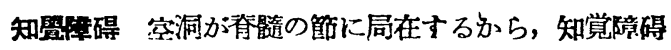
も節狀性を呈するのは当然で, その部位から空洞の存在 部位を逆倠定することが出来る。しかも顆の場合とは 異なり,ゆわゆる知孟解雉 (Dissociation of sensation) の現象を件らのが常で，これ夹に本昰の特徽をなするの である。元来末梢神経縅維中, 溫度覚扣よび涌覚の織雃

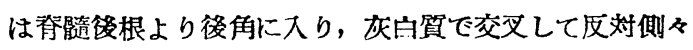
索を上昇するが，䪅賞䋐維は一部後根より後触人万， 交叉して反対侧後索を土犁し，一部は交叉せず後根より 
值ちに同側後素を上昇する。しかるに本症に特ける空洞 形成は䀧ね一侧の後解生ずることが多く，従つてその

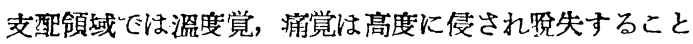
も多いが，觸覚は一部分保存されて 牫存するわけであ る。知覚解誰は本症㱠んど必発とも言5べきもので， 診断上重要であるが，禁洞形成の部位如何では知覚障碍 ぞれ自体が軽徵で，溫搴覚，痛覚の䧛碍すら不明膫であ ることも少くない（作藤・本間, 田嶼, 津田, 月村, 山 口)。また空洞形成の蕉行が等激なら，栄㝨障碍が顯著

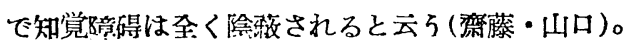

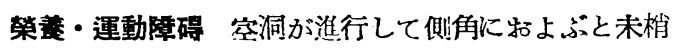

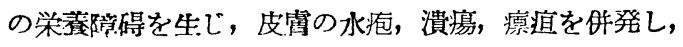
更に爪, 筇, 骨の瘘縮を来し, 前角も侵されて未梢部に

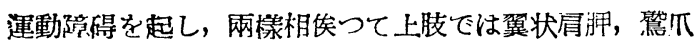

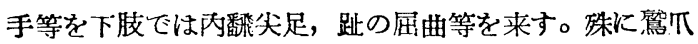
手を軽雨の盖こそあれ，最もしばしば見られる症状であ

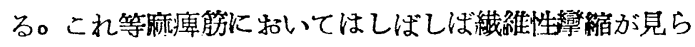
れ，手指震䫓は本症の一特徽でさえある。また空洞形成 が灰白質を越えて，白質殊に侧索洼するなら，錐体道 か障碍されて下肢で犍反射が六進し、Rabinski, Mendel, Oppenheim 等の, 的反射が見られ，運動失

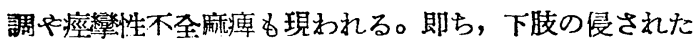
22例中18例では步行团踓若しくは不能 (白川, 中村, 渎 藤・本間, 碓居, 石山, 津田) があつた。次に躯幹筋に

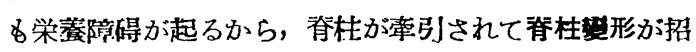
来される。但し吳・沖中の研究によると脊柱放形の原因 は，罢ろ脊椎骨それぞれ自身の栄盖障碍によるものが最 大であると云う。孰れにしても (27.4\%) を算し，侧督 (辻, 西野, 中田 - 吉田 2 例, F田, 吳, 奥瀨 -7 例) 最も多く，後彎（青山，佐藤・偩山）これに头ぎ，時に は兩者合垪する (山口, 周々木・大橋, 碓居, 井上・光 沢, 知鳥・本荘一 5 例)。時には反対に胸骨の船底状陷 没も見られる。

夷に本症にかなり特有の症状に眼䁴孔現象がある。即 ち瞳孔不同症，対光反射の連鈍の外，ゆわゆる Horner 氏現解即亏眼球後退，眼裂狹少，瞳孔縮少，眼睑下垂等

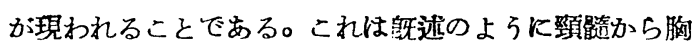
髓にかけて好発部位である事実と一敘し，該部にある眼 に分布する交感神経中塸が侵されるからである（井上・ 光沢, 石山, 加藤, 中野, 西野, 島薗, 周々木, 辻, 碓

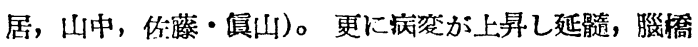

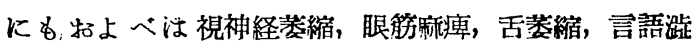
滞, 镕下纣難等の球症狀を招来するのは当然である (Syringobulbia) (井上- 光沢, 西野, 猿渡, 島薗, 周

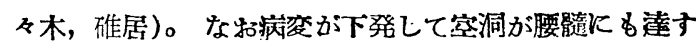
れば，膀腃值腸症状を来し得る。また聜洞の侻置如何て は Brown-Seaquard 症候群を来す場合もあろう（石 山, 木村)。

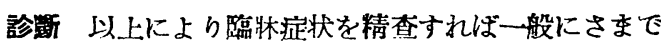
团踓でないが，脊娟撮影泆が時に有効である（中田・吉

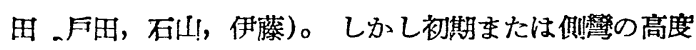
な埣合には不適当であると云ら(中田・吉田)。

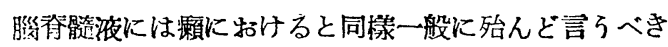
所見なく，前記51例中その記載ある20例中では僅かに 3 例で, Pandy 反応陽性を呈したのみであつた(河合・大

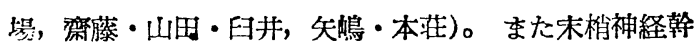
の肥厚は瀨とは異なり，通常見られないか，时腺が細長く

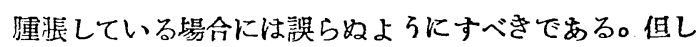
月村特よびわれわれの第2例では大耳介神経がやや太く 觸知されたが，われわれの垶合組織学的にはほぼ正常で あつた。

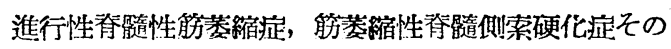

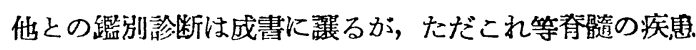
を適嬳に鑑別することは時に簡単でないこともあろろ。 即ち最近櫻井・犀川の記載した 1 例の如きは正にその類 のものである。

治療 初期にはレ線治療が有效で，水腫の高度のもの では Syringotomy がよいと云う（石山，中田・吉田， 津田)。

\section{結語}

兩_上肢の知覚および運動・栄盖の障碍, 鴐爪手を主症 状とする48才の女子，站に四肢の知覚およひ運動・栄素

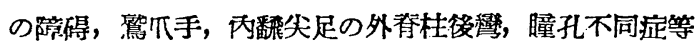
を主症状とする39才の女子の脊鋳空洞症を報告し，併せ て本邦に打け報告例と対比しつつ, 本症の臨牀を検討し 頪との監別に凟した。それにより，われわれの例は臨彇 的に夯の如く考えることが出来よう。

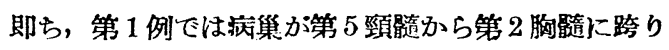

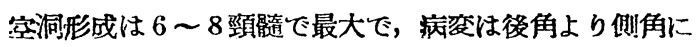

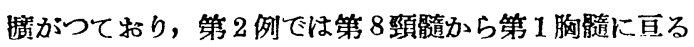

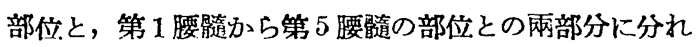
て空洞を形成し，しかも病帘は後角より側角に打よんで いるのは勿論，更に侧索をも压迫していると考えられ ろ。 
佐藤・真山論交附図

写盾 1

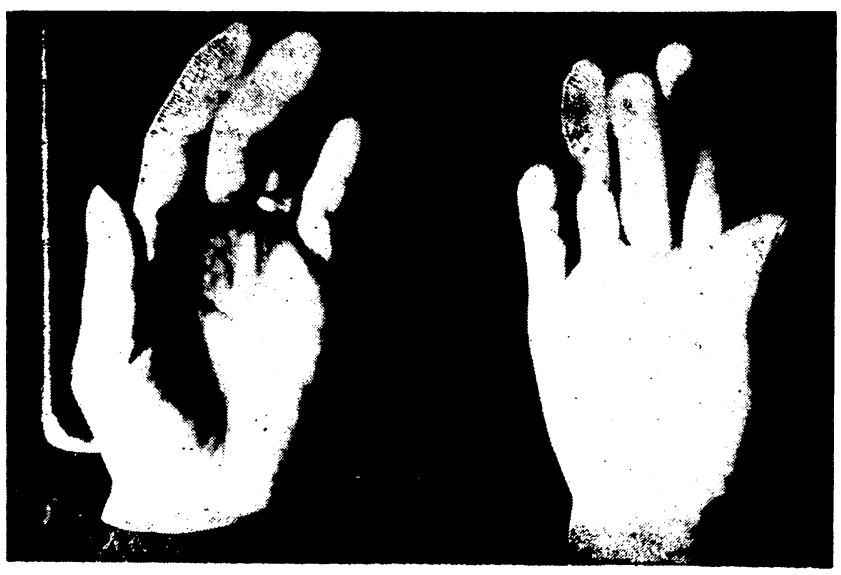

写官

2
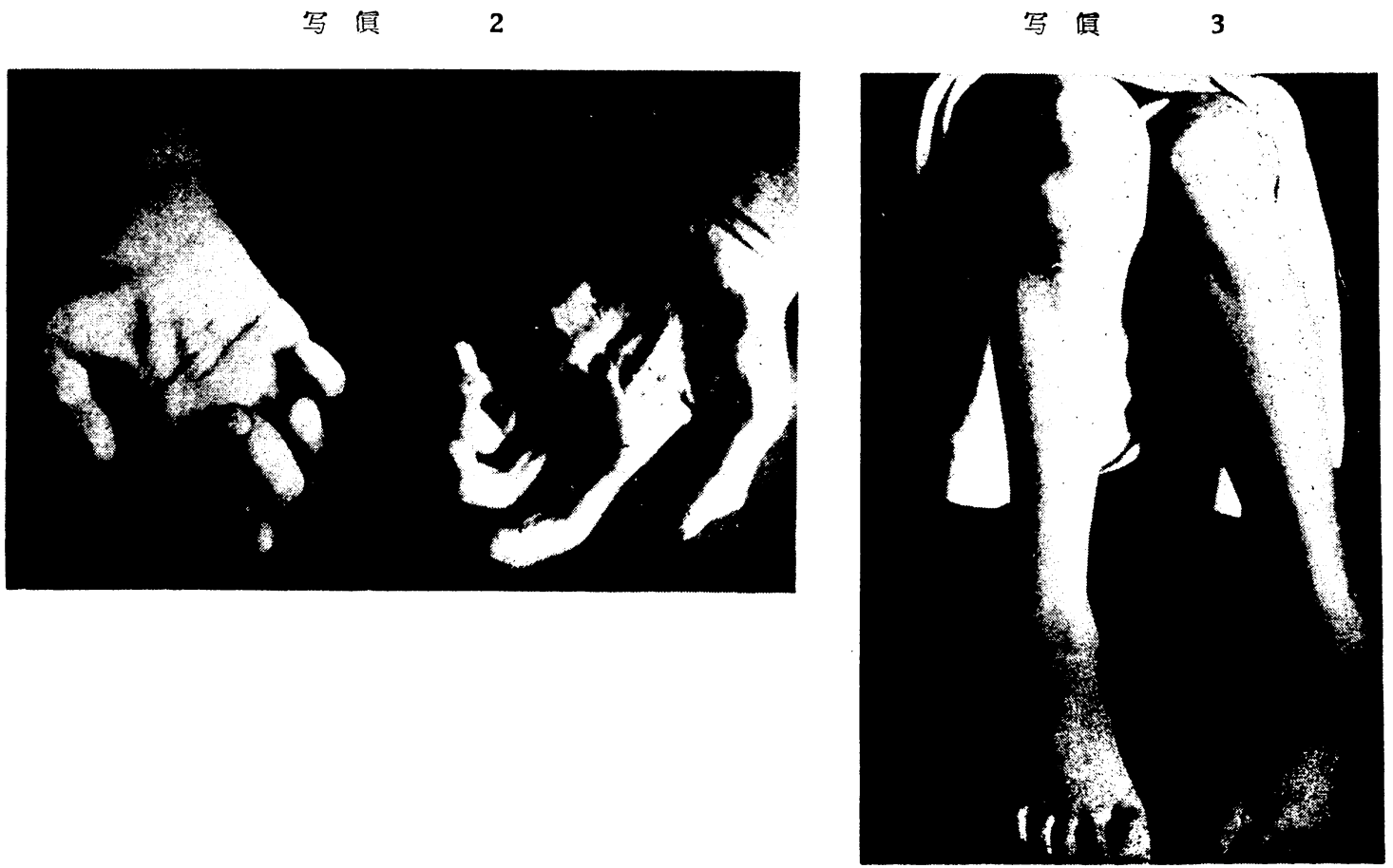

IIP 


\section{文献}

1) 青山：神経誌，1918，17，6898

2) 安滕：北娍矢誌， I930，45，509。

3) 稳田 : 奏地医家と監休, 1928，5719。

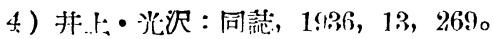

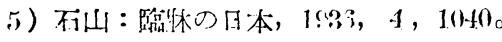

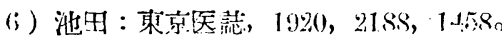

7 ）伊藤：外科, 1997, 1, 7纣

s）岩男：䠛休の月本，1940, $s, 458$ 。

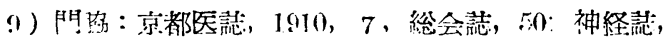
$1913,12,11$, , 81), 175。

11)）上经：內外治療，1922， $7,140 \Omega$ 。

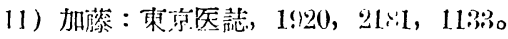

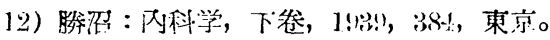

13) 川口：東京医会詋: 1980， \%, 996。

14）河合 - 大庭：奄医誌，1939，316，951。

15) 河路：北题医誌，1927，52，81t。

16）木村：大阪医誌，1982，3，1385。

17）: 矢駼医報，192\%，21，1059。

18）吴・沖中：自律神経丞，1949，万版，東京。

19）丸山：軍医沇，1910，14，43\%。

20）三湤：東京医会誌，1889，3，43，605。

21）中田・吉田：グレンツゲビート，1233，7，19。

22) 中村：北㣝医誌，1!18，3，182。

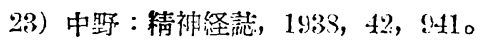

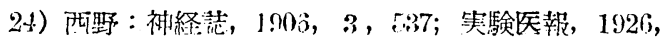
$12,1+40$ 。
25）新田：月本內科䛠，1924，12，561。

26）大橋：合數中央病院年報，1927，2，12!。

27）奧瀨：千谋医誌，1942，21，No. 6，3i。

28）齋藤・山时・团井：軍医誌，1941，342，1691。

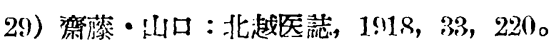

30）櫻井・㟁川：東京医誌，1951，68, No. 2，36。

31）踦山：治嘹及処方，1941，22 104。

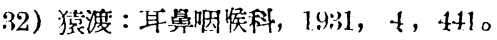

33）佐々木：日本內科蓅，1932，20，730。

Bt）佐藤・本間：神経誌，1918，17，111。

35) 柴：月本內料哂， $1926 ， 14 ， 6055$ 。

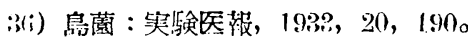

37）由川：第9回日本內科莣，1912，507。

88）周々木：寒験腿科誌，1927，10，396。

29）田端：日本內科誌，1980， 17，889。

4 (1) 田嶼：外科, 1948, 7, 911。

41）津田：実地医家と臨牃，1938，15，112。

42）塚田：日本內科誌，1980，18４483。

43) 戶田：稫岡医誌，193?，26，1826。

44）月村：日本医学使像保険，1941，8289，1684。

45) 辻：臨㸱木, 1925, 2, 368。

46) 碓居: 実験医城, $1128,14,1264$ 。

47）矢花：日本外战誌，1921，22，249。

48）矢昜・本䓅：東京医誌， $1950 ，(67$, No. 2，36。

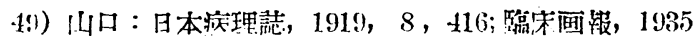
$\therefore$ No. 6 。

5(1) 山中：筷験眼䎴誌，1926，9，19\%。 